\title{
Glossary of Hebrew/Yiddish terms used in the text
}

\author{
Aliyah \\ Emigration to Israel \\ Ashkenazi, pl. Ashkenazim Jews originating in Central and Eastern \\ Europe. \\ Barmitzvah \\ Beth HaMedrash \\ Coming of age ceremony for boys aged 13 \\ Religious study hall often attached to a \\ synagogue \\ Beth Din \\ Religious court \\ Bimah \\ Reading platform, traditionally centrally \\ placed in Ashkenazi synagogues \\ Charedi \\ Cheder (heder) \\ Ultra-Orthodox Jews \\ Part-time religious school \\ Chevroth \\ Small self-administered religious \\ congregation \\ Frumkeit \\ Religious observance, piety. See also \\ Yiddishkeit \\ Habonim \\ Hazan (chazan) \\ Zionist youth group \\ Cantor \\ Hevrah kadisha \\ Burial society; voluntary society which \\ prepares the dead for burial \\ Kashrus/t \\ Keeping the dietary laws \\ Kibbutzim \\ Collective farms in Israel \\ Kolel \\ Joint enterprise association of rabbis \\ Landsman/landsmanshaft \\ Litvak \\ A person hailing from the same town of origin \\ Jews originally from the Lithuanian and Baltic \\ region \\ Luhot \\ Tablets of the Law, dual stone bearing the Ten \\ Commandments
}


Magen David

Menorah

Mikveh

Minyan

Ohel pl. Ohelim

Polak

Schmatter

Sefer Torah, pl. Sifrei

Sephardi, pl. Sephardim

Shechita (Board of)

Shechitah

Shool/shul

Shtiebl

Succah

Succot

Talmud Torah

Treife

Yeshiva

Yiddishkeit (lit.) Shield of David. Star of David emblem

Seven-branched candelabrum. Popularly used to refer to the nine-branched candelabrum lit on the festival of Hanukah

Women's ritual bath. Sometimes found in the basement of a synagogue Quorum of 10 males, over the age of 13, required for collective worship Prayer hall at a cemetery Jews originally from Polish regions Rags, as in 'the rag trade', i.e. textiles and clothing industry

Scrolls of the Law containing the Pentateuch, stored in the synagogue Ark

Jews originating from the Iberian Peninsula Organisation ensuring the provision of kosher meat for the community Jewish ritual slaughter of animals for kosher food

Synagogue

Small, sometimes domestic, prayer meeting place

Temporary booth open to the sky erected to celebrate the festival of Succot Festival of 'Tabernacles' or 'Booths' Religious primary school for children Description of food not permitted for consumption by Jews Rabbinical religious seminary for young men Traditional Judaism 